\title{
Implementasi E-Commerce B2C Bahasa Jawa untuk UMKM Jolali KaoSemarang
}

\author{
Satriyo Adhy ${ }^{1)}$, Panji Wisnu Wirawan ${ }^{2)}$, Sukmawati Nur Endah ${ }^{3)}$
}

Jurusan Ilmu Komputer / Informatika, Fakultas Sains dan Matematika, Universitas Diponegoro satriyo@.undip.ac.id ${ }^{1)}$, maspanji@.undip.ac.id ${ }^{2)}$, sukma_ne@.undip.ac.id $^{3)}$

\begin{abstract}
Abstrak
Jolali KaoSemarang adalah UMKM (Usaha Mikro, Kecil dan Menengah) yang memproduksi kaos dan souvenir dengan desain kreatif. Jolali KaoSemarang memiliki dua lini yaitu produksi pemesanan kaos custom dan lini produksi kaos yang menunjukkan kekhasan kota Semarang. Aplikasi E-Commerce Jolali dikembangkan dengan mengangkat tema Bahasa Jawa sebagai unsur tambah komunikasi antara Jolali dan pelanggan. Aplikasi ecommerce bahasa Jawa dibangun secara iteratif dengan beberapa rilis. Metode tersebut mengadaptasi metode DSDM (Dynamic System Development Method) yang merupakan salah satu metode pengembangan perangkat lunak tangkas. Aplikasi E-Commerce Jolali yang dihasilkan dapat membantu Jolali KaoSemarang untuk memperluas pemasaran, mempermudah pengolahan produk dan transaksi dan dapat memfasilitasi pemesanan produk dari jarak jauh tanpa harus bertatap muka. Fitur Bahasa Jawa sebagai bahasa komunikasi antara pihak Jolali dan Pelanggan telah diimplementasikan sehingga dapat lebih mempererat hubungan kedua belah pihak.
\end{abstract}

Kata Kunci : UMKM Jolali, E-Commerce, DSDM, Bahasa Jawa, Komunikasi

\section{Pendahuluan}

Kota-kota besar di Indonesia pada dasarnya memiliki keunikan-keunikan tersendiri. Keunikan dalam hal kuliner dan tempat-tempat wisata menjadi daya tarik kunjungan turis ke kota-kota besar tersebut. Kota Semarang sebagai ibukota provinsi Jawa Tengah memiliki banyak keunikan. Kuliner khas seperti lumpia dan bandeng, kemudian bangunan-bangunan tua seperti Lawang Sewu, Kota Lama, dan yang lain menjadi daya tarik turis untuk berkunjung ke Kota Semarang. Keunikan-keunikan di Kota Semarang dijadikan peluang oleh industri kreatif untuk dituangkan dalam bentuk grafis yang menarik sehingga desain grafis tersebut diminati dan dijadikan buah tangan khas Kota Semarang. Salah satu industri kreatif tersebut adalah Jolali.

Jolali merupakan UMKM yang bergerak dalam bidang produksi kaos. Kaos yang dihasilkan memiliki desain unik yang menunjukkan ciri khas kota Semarang. Selain produksi kaos, unit usaha ini memproduksi cendera mata seperti mug dan tas. Selain produksi kaos dan sovenir, Jolali melayani pemesanan kaos dengan custom baik dari institusi maupun pribadi. Desain tersebut khusus atas permintaan pemesan.

Selain toko untuk pemasaran, Jolali memanfaatkan blog yang beralamat di http://jolalikaosemarang.blogspot.com/ dan http://lisanjolali.blogspot.com sebagai alternatif pemasaran. Blog tersebut menampilkan informasi produk jadi Jolali, lokasi dan detail kontak tokonya, namun pengunjung tidak dapat memesan secara online. Hal ini yang membatasi calon konsumen untuk memesan produk kaos dan sovenir. Selain itu, tidak ada informasi khusus bahwa Jolali menerima pemesanan kaos custom. Informasi yang ditayangkan hanya informasi telah dipesan kaos custom oleh berbagai perusahaan. Hal tersebut menjadi kendala untuk memasarkan produk.

E-commerce merupakan tipe perdagangan yang memanfaatkan internet sebagai media transaksi. Pada umumnya, E-commerce dikembangkan memanfaatkan teknologi www (world wide web) atau disingkat web. Ecommerce dapat digunakan menyajikan katalog produk yang dapat dilihat oleh semua pengguna internet di seluruh dunia. Pengguna internet dapat memilih produk, kemudian membeli produk menggunakan fasilitas transfer bank ataupun memanfaatkan kartu 
kredit untuk pembayaran. Kemudahan inilah yang dapat memperbanyak proses transaksi keuangan. E-commerce pun memungkinkan interaksi antara penyedia produk dengan pengguna internet yang tertarik dengan produk yang disediakan. Pengguna internet dapat melakukan olah pesan (messaging) dalam bentuk buku tamu (guest book), chatting dan surel (e-mail). Dengan demikian, hubungan antara penyedia produk dengan pelanggan bisa ditingkatkan. Informasi-informasi mengenai produk baru dapat diberikan secara privat ke pada pengguna internet yang tertarik dengan produk yang disediakan. Pada sudut pandang global, E-commerce memiliki dampak terhadap perdaganagan internasional, yang berakibat pada hasil, harga, impor, ekspor perdagangan cendera mata, dan lain-lain[5]. Di India, ditemukan bahwa e-commerce memiliki dampak yang signifikan dan positif terhadap proses bisnis perdagangan UMKMnya[2].

Bahasa Jawa yang merupakan bahasa daerah yang hidup di kalangan masyarakat Jawa khususnya daerah Jawa Tengah dan Timur. Di dua propinsi ini bahasa Jawa dengan dialeknya masing-masing. Bahasa Jawa sering digunakan dalam berbagai segi kehidupan termasuk dalam bidang perdagangan. Potensi bahasa ini dapat dipergunakan sebagai sebuah jembatan komunikasi dalam memasarkan produk yang dimiliki UMKM Jolali KaoSemarang.

Berbagai potensi baik dari UMKM Jolali maupun e-commerce dirangkum menjadi satu dalam sebuah pengembangan perangkat lunak. Berbagai macam metode pengembangan perangkat lunak seharusnya disesuaikan dengan ciri khas atau karakteristik dari proyeknya, hal ini dilakukan untuk mendapatkan hasil yang optimal. Melihat jenisnya, pengembangan e-commerce mengedepankan kecepatan, kemudahan dan fleksibilitas sehingga pengembangan yang bersifat agile menjadi sangat diperlukan[3][4], salah satunya adalah DSDM (Dynamic System Development Method).

\section{Dasar Teori}

Perkembangan teknologi informasi yang pesat mengakibatkan peningkatan aktivitas bisnis yang pesat pula terutama dalam bidang perdagangan. Implementasi teknologi informasi dalam bidang perdagangan melahirkan sarana jual beli baru yang dikenal dengan E-Commerce. Dengan adanya $E$ Commerce, kegiatan pemasaran dan transaksi produk atau jasa baik dalam bentuk fisik atau digital dapat dilakukan secara online.

\subsection{Pengertian E-Commerce}

Laundon Kenneth pada buku " $E$ Commerce: Business, Technology, and Society", mengatakan bahwa E-Commerce adalah kegiatan bisnis yang menggunakan internet dan teknologi website[1]. Transaksi $E$ Commerce berfokus pada transaksi bisnis yang dihubungkan oleh teknologi digital dan transaksi komersial yang melibatkan pertukaran mata uang diantara organisasi dan individual dengan syarat mendapatkan barang maupun jasa.

\subsection{Dynamic System Development Method}

Dynamic System Development Method (DSDM) yang merupakan salah satu metode pengembangan perangkat lunak tangkas (agile software method). Rilis (release) dalam pengembangan DSDM terbagi menjadi dua, yaitu : rilis fitur dasar sistem dan rilis fitur pendukung. Rilis fitur dasar sistem berfungsi untuk mengidentifikasi peran pengguna, sedangkan rilis fitur pendukung melengkapi seluruh kebutuhan sistem yang akan dikembangkan.

\section{Pembahasan}

Solusi untuk permasalahan pada Jolali adalah solusi sistem e-commerce bahasa Jawa. Pengembangan sistem e-commerce bahasa Jawa untuk Jolali dilaksanakan dengan beberapa tahapan metodologi, seperti yang terlihat pada Gambar 1. 


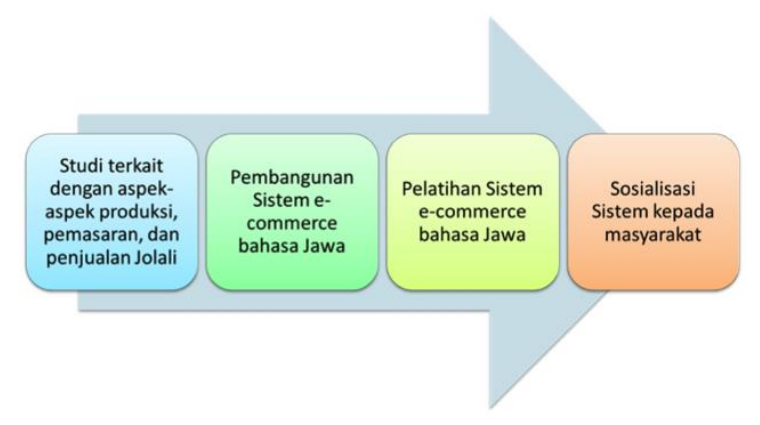

Gambar 1. Metodologi

\subsection{Studi Terkait Dengan Aspek Produksi, Pemasaran, dan Penjualan Jolali}

Tahapan ini merupakan tahapan paling awal yang digunakan untuk mengumpulkan berbagai data terkait dengan aspek produksi, pemasaran, dan penjualan Jolali pada kedua lini. Tim mencermati proses bisnis yang berlaku dan melakukan serangkaian wawancara untuk menggali permasalahan, menggali kebutuhan Jolali dan kemudian mengkaitkan dengan solusi berbasis teknologi informasi.

Luaran dari tahapan ini adalah spesifikasi kebutuhan sistem e-commerce bahasa Jawa secara detail, baik kebutuhan fungsional maupun non-fungsional sistem. Kebutuhan fungsional terkait dengan apa yang bisa dilakukan sistem atau fitur-fitur yang membentuk fungsionalitas sitem. Sedangkan kebutuhan non-fungsional terkait dengan kebutuhan diluar kebutuhan fungsional yang mendukung kebutuhan fungsional seperti kebutuhan dalam hal penggunaan sistem (usability), performa sistem, ketersediaan (availability), dan keamanan (security).

\subsection{Pembangunan Sistem e-commerce bahasa Jawa}

Pembangunan sistem e-commerce bahasa Jawa mengedepankan pembangunan untuk mendukung pemasaran, pemesanan online dan komunikasi dengan pelanggan. Namun sebelumnya, harus dibangun fitur dasar untuk mendefinisikan peranan pengguna sistem. Pendefinisian peranan pengguna ini penting untuk membedakan peranan lini produksi Jolali.

Aplikasi e-commerce bahasa Jawa yang dibangun merupakan perangkat lunak berbasis web. Dari aspek pengembangan perangkat lunak, aplikasi e-commerce bahasa Jawa dibangun secara iteratif dengan beberapa rilis (release), dimana setiap rilis merupakan bagian sistem yang dapat digunakan oleh pihak Jolali. Metode tersebut mengadaptasi metode DSDM (Dynamic System Development Method) yang merupakan salah satu metode pengembangan perangkat lunak tangkas (agile software method). Rilis dari sistem $e$ commerce bahasa Jawa yang dibangun adalah terbagi menjadi rilis fitur dasar dan rilis fitur pendukung.

A. Rilis Fitur Dasar Sistem

Fitur dasar sistem yang paling utama adalah pendefinisian peranan pengguna sistem (user roles). Pendefinisian pengguna ini menentukan siapa boleh mengakses apa saja. Berdasarkan studi awal, setidaknya ada 2 peran pengguna sistem yaitu pertama adalah administrator yang akan mengelola bagian produksi kaos dan bagian produksi kaos custom, dan yang kedua adalah konsumen/pelanggan Jolali.

Dalam rilis ini, peran pengguna sistem dimanfaatkan untuk otorisasi sistem, jadi pada rilis ini setidaknya pengguna dari masingmasing peran, sudah dapat memiliki otoritas untuk mengakses sistem. Pengguna dari masing-masing peran dapat melihat tampilan awal web e-commerce bahasa Jawa, dan melakukan otorisasi untuk masing-masing peran.

B. Rilis Fitur Pendukung Pemasaran

Fitur pendukung pemasaran, terkait dengan katalog produk dan sovenir yang diproduksi oleh Jolali, serta layanan informasi pemesanan kaos custom. Secara garis besar, lini produksi kaos dan kaos custom sudah dapat memanfaatkan fitur ini untuk pemasaran, mulai dari mengatur katalog produk, mengatur informasi produk dan mendistribusikan informasi terkait dengan produk kepada konsumen secara elektronik.

C. Rilis Fitur Pendukung Pemesanan Online 
Fitur pemesanan online merupakan fitur dimana pengguna internet dapat memesan barang-barang produksi Jolali secara online. Pembayaran dapat dilakukan secara manual maupun elektronik, sesuai permintaan dari pihak Jolali. Setelah pengguna memesan, secara real-time pemesanan tersebut sampai ke pihak Jolali dan pihak Jolali dapat segera menindak lanjuti dengan pengiriman dan konfirmasi kepada pemesan, dimana konfirmasi dapat dilakukan secara elektronik dengan fitur ini.

D. Rilis Fitur Pendukung Komunikasi Pelanggan

Komunikasi dengan pelanggan adalah satu hal yang penting untuk membuat pelanggan 'setia' dengan Jolali. Selain itu, pengguna internet secara umum dapat mengirimkan pesan kepada pihak Jolali dan pihak Jolali dapat membalas pesan yang dikirimkan tersebut melalui sistem e-commerce bahasa Jawa. Dalam fitur ini, pengguna produk Jolali pun dapat memberikan testimoni terkait dengan produk-produk Jolali, sehingga testimoni ini dapat memberikan panduan pada pengguna internet yang tertarik dengan produk-produk Jolali.

\section{E. Arsitektur Sistem}

Sistem e-commerce bahasa Jawa yang dibangun memiliki arsitektur 3-tier (three tier) dimana sistem terdiri dari 3 elemen yaitu presentation tier, business logic tier dan data tier saperti ditunjukkan oleh Gambar 2. Presentation tier merupakan antarmuka sistem (system interface) antara pengguna internet / pelanggan Jolali dengan sistem e-commerce bahasa Jawa. Pengguna internet/pelanggan Jolali dapat memanfaatkan komputer personal (PC), laptop maupun smartphone. Antarmuka tersebut bertugas untuk meneruskan data yang diminta pengguna tersebut ke business logic tier. Business logic tier memproses data yang diminta. Jika membutuhkan data, bussiness logic tier meminta kepada data tier yang bertugas untuk mengatur bagaimana data disimpan pada sistem basis data.

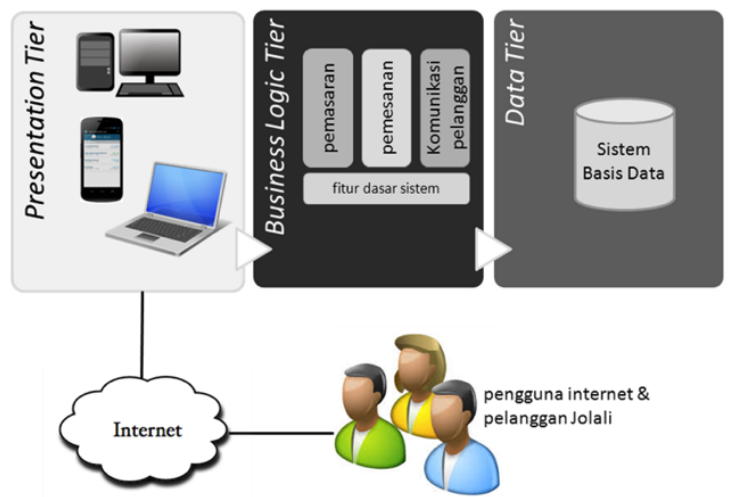

Gambar 2. Arsitektur sistem e-commerce bahasa Jawa.

\subsection{Pelatihan Sistem e-commerce bahasa Jawa}

Pelatihan sistem dilakukan kepada pihak Jolali untuk kedua lini produksi. Pelatihan ini bertujuan supaya pihak Jolali dapat menggunakan sistem e-commerce bahasa Jawa secara optimal. Selain pelatihan, pendampingan pun dilakukan pada awal-awal penggunaan sistem e-commerce bahasa Jawa.

Untuk dapat mengembangkan sistem $e$ commerce bahasa Jawa pada masa mendatang, dokumentasi teknis terkait dengan pengembangan perangkat lunak diikutsertakan setelah sistem $e$-commerce bahasa Jawa selesai secara keseluruhan. Selain itu, untuk menghindari ketergantungan terhadap tim pengembangan, user manual dari sistem $e$ commerce bahasa Jawa pun diberikan kepada pihak Jolali.

\subsection{Sosialisasi Sistem kepada masyarakat}

Sosialisasi sistem e-commerce bahasa Jawa kepada masyarakat dapat dilakukan dengan memberikan informasi mengenai sistem ini kepada masyarakat pada berbagai event seperti Semarang Fair. Sosialisasi pun juga dilakukan pada saat perkumpulanperkumpulan komunitas yang ada di Semarang seperti komunitas Blog Semarang, komunitas produsen kaos dan sebagainya.

Untuk mendukung web e-commerce bahasa Jawa Jolali diindeks oleh mesin pencari (search engine) di internet seperti Google, AllTheWeb dan yang lain, optimasi pun 
dilakukan. Hal ini supaya Jolali menempati ranking tertinggi dalam pencarian mesin pencari.

Diharapkan dengan cara-cara tersebut di atas, web e-commerce bahasa Jawa Jolali semakin dikenal masyarakat luas. Produk Jolali diharapkan mampu untuk bersaing dan menjadi ikon Kota Semarang seperti halnya Joger dan Dagadu yang menjadi ikon kota Yogyakarata dan Bali.

\section{Hasil}

Tahap ini menyajikan hasil penelitian yang dikaji dari sudut pandang penggunaan multi bahasa, fitur aplikasi, alur pembelian produk, dan alur pemesanan produk.

\subsection{Bahasa}

Perangkat lunak yang telah dikembangkan untuk UMKM Jolali memiliki dua bahasa, yaitu : Bahasa Indonesia dan Bahasa Jawa. Bahasa Jawa ini dipergunakan untuk dapat lebih mempererat komunikasi antara UMKM Jolali dengan konsumen maupun partner bisnis. Secara umum pergantian bahasa dari Bahasa Indonesia menjadi Bahasa Jawa dapat dilakukan dengan sekali klik sebuah tombol yang berada di halaman beranda ataupun halaman yang lainnya. Perbedaan bahasa dapat dilihat pada Gambar 3 dan Gambar 4.

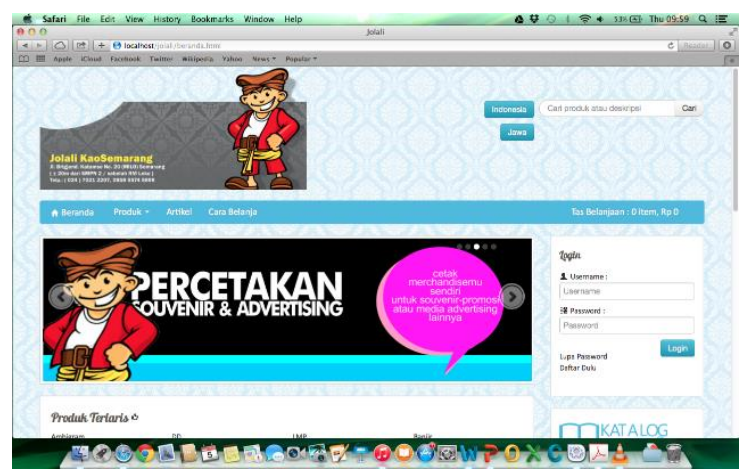

Gambar 3. Halaman Beranda Berbahasa Indonesia

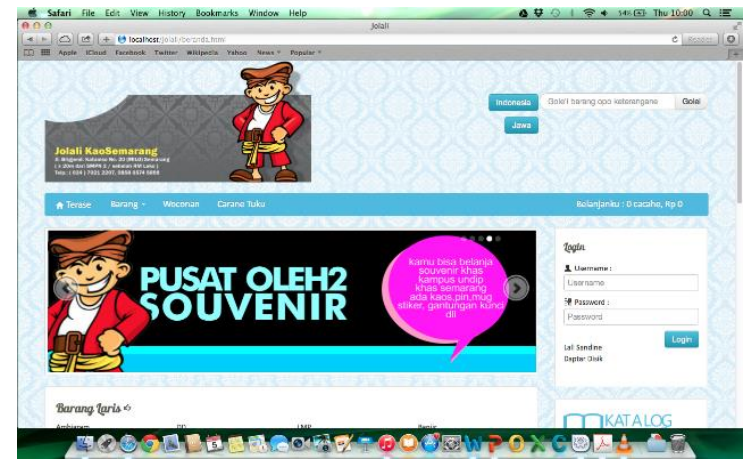

Gambar 4. Halaman Beranda Berbahasa Jawa

\subsection{Fitur E-Commerce}

Pengembangan perangkat lunak $E$ Commerce Jolali Bahasa Jawa (selanjutnya disebut aplikasi) dibagi menjadi dua bagian berdasarkan peran pengguna, yaitu : Administrator atau Manajemen Jolali dan Pembeli atau Pelanggan. Pembahasan dari dua sisi peran pengguna adalah sebagai berikut:

A. Administrator

Seorang administrator dapat melakukan berbagai langkah untuk mempersiapkan, mengisi, memproses, hingga mengirimkan produk kepada pelanggan dengan memberikan informasi pengiriman berupa nomor "resi" dari suatu penyedia jasa expedisi pengiriman. Beranda Administrator akan berisi resume aktifitas penjualan seperti yang terlihat pada Gambar 5.

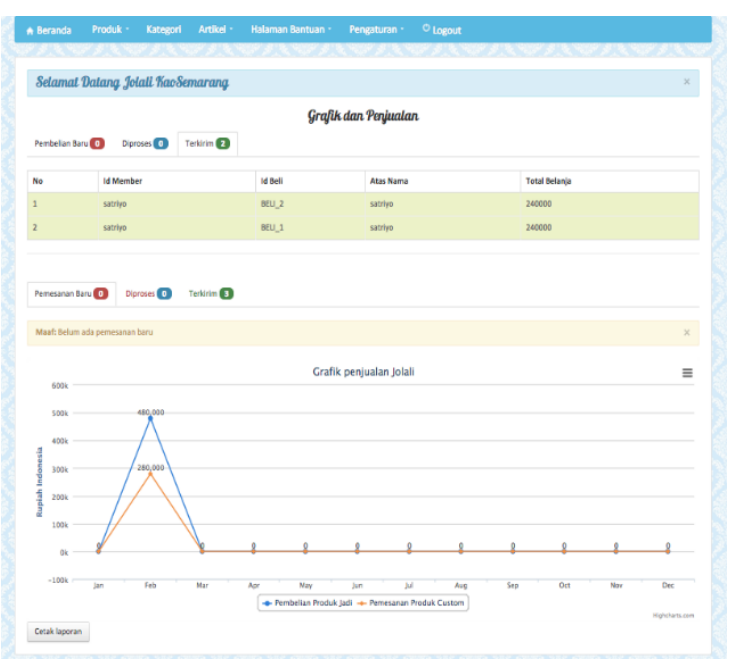

Gambar 5. Halaman Beranda Administrator 
Pada beranda, administrator dapat melihat secara cepat dua lini produksi UMKM Jolali KaoSemarang melalui aplikasi ini yaitu : pembelian produk dan pemesanan produk custom dari pelanggan, selain itu disajikan pula grafik penjualan dari kedua lini produksi tersebut. Jumlah administrator dapat lebih dari satu sehingga nantinya dapat dibagi-bagi tugas sesuai beban kerjanya setiap orang.

Fitur-fitur yang dapat digunakan oleh seorang administrator adalah :

1. Manajemen Produk

Fitur ini digunakan untuk menambah, mengedit, dan menghapus produk.

2. Manajemen Kategori Produk

Fitur ini digunakan untuk menambah, mengedit, dan menghapus kategori produk.

3. Manajemen Artikel

Fitur ini digunakan untuk menambah, mengedit, dan menghapus artikel atau informasi yang ingin disampaikan oleh manajemen Jolali kepada pelanggannya.

4. Manajemen Halaman Bantuan

Fitur ini digunakan untuk menambah, mengedit, dan menghapus halaman bantuan yang diberikan oleh manajemen Jolali dalam rangka membantu memberikan arahan atau petunjuk penggunaan aplikasi E-Commerce Jolali.

5. Manajemen Pengaturan Halaman Situs

Fitur ini digunakan oleh administrator manajemen Jolali untuk mengatur berbagai macam isian situs web seperti : identitas Jolali beserta alamat maupun informasi yang lain, dapat digunakan untuk merubah gambar banner, mengubah data administrator, menambah administrator, mengelola testimonial, dan mereset password anggota atas permintaan anggota.

B. Pelanggan

Seorang pelanggan dapat melakukan berbagai langkah untuk membeli atau memesan produk yang disajikan oleh aplikasi E-Commerce Jolali. Jika hanya ingin melihat produk yang dimiliki Jolali maka seorang pelanggan tidak diperlukan login ke dalam aplikasi, namun jika ingin membeli atau memesan maka seorang pelanggan diwajibkan login atau registrasi terlebih dahulu sebelum melakukan transaksi.

Fitur-fitur yang dapat dipergunakan seorang adalah :

1. Beranda

Fitur ini menyajikan kepada pelanggan tampilan produk dengan kemunculan produk versi terlaris maupun produkproduk baru dari Jolali.

2. Kategori Produk

Fitur ini menyajikan produk kepada pelanggan berdasarkan kategorisasi yang telah disiapkan oleh administrator. Kemunculan kategorisasi produk dapat dilihat secara sajian datar maupun secara katalog album.

3. Membaca Artikel

Fitur ini menyajikan pelanggan berbagai macam informasi yang ingin disampaikan oleh manajemen Jolali dalam rangka meningkatkan keakraban dan loyalitas pelanggan.

4. Bantuan Cara Belanja

Fitur ini menyajikan tata cara berbelanja dalam aplikasi E-Commerce Jolali.

5. Manajemen Akun dan Belanja

Fitur ini menyajikan berbagai menu perbelanjaan yang dapat dilakukan oleh Pelanggan mulai dari riwayat data perbelanjaan, memberikan testimonial, menghubungi administrator, dan mengubah data pelanggan.

\subsection{Alur Pembelian Produk Jadi}

Pembelian produk jadi dihasilkan oleh Jolali didalam aplikasi E-Commerce Jolali disajikan dalam urutan :

1. Memilih barang yang akan dibeli untuk kemudian dilakukan klik beli, pada bagian ini dilakukan berulang-ulang hingga semua barang yang diinginkan telah masuk ke dalam keranjang belanja

2. Melihat dan mengupdate keranjang belanja serta alamat pengiriman

3. Menyelesaikan belanja dan melihat riwayat belanja

4. Menunggu Administrator melakukan pemrosesan pembelian barang 
5. Melakukan pembayaran kepada pemilik Jolali, hal ini dilakukan diluar sistem

6. Melakukan konfirmasi pembayaran dan menggunggah bukti pembayaran

7. Menunggu Administrator melakukan pemrosesan konfirmasi pembayaran

8. Melihat status pembelian atau riwayat belanja dan melacak pengiriman dari nomor resi yang diberikan oleh Administrator

\subsection{Alur Pemesanan Produk Custom}

Pembelian produk custom dihasilkan oleh Jolali didalam aplikasi E-Commerce Jolali disajikan dalam urutan :

1. Masuk kedalam menu kategori produk dan memilih pemesanan produk custom

2. Mengisi halaman pemesanan produk custom dengan mengupload file gambar, meletakkan pada posisi yang diinginkan, memilih warna dasar, mengisi ukuran, jumlah pesanan, spesifikasi lain(keterangan), dan alamat kirim

3. Menyelesaikan belanja dan melihat riwayat belanja

4. Menunggu Administrator melakukan pemrosesan produk custom dan memberikan harga

5. Melihat total pembelian produk custom

6. Melakukan pembayaran kepada pemilik Jolali, hal ini dilakukan diluar sistem

7. Melakukan konfirmasi pembayaran dan menggunggah bukti pembayaran

8. Menunggu Administrator melakukan pemrosesan konfirmasi pembayaran

9. Melihat status pembelian atau riwayat belanja dan melacak pengiriman dari nomor resi yang diberikan oleh Administrator

\section{Kesimpulan}

Aplikasi E-Commerce Jolali yang dihasilkan dapat membantu UMKM Jolali KaoSemarang untuk memperluas pemasaran, mempermudah pengolahan produk dan transaksi dan dapat memfasilitasi pemesanan produk dari jarak jauh tanpa harus bertatap muka. Fitur Bahasa Jawa sebagai bahasa komunikasi antara pihak Jolali KaoSemarang dan Pelanggan telah diimplementasikan sehingga dapat lebih mempererat hubungan kedua belah pihak. Fitur-fitur yang lain dibangun berdasarkan kemudahan interaksi antara pelanggan dan Jolali, sehingga lebih mempermudah proses transaksi pembelian produk maupun pemesanan produk custom.

Pengembangan dan implementasi bahasa Jawa merupakan salah satu cara membuat jati diri E-Commerce Jolali, pengembangan bahasa lebih lanjut dapat diarahkan kepada area pemasaran yang lebih luas seperti bahasa yang bersifat internasional atau berbagai bahasa yang lainnya. Pengembangan bahasa komunikasi wajib menjadi bahan perhatian mengingat kita hidup didalam era perkembangan dunia yang semakin terbuka dan meminimalisasi batasan pulau bahkan Negara.

\section{Ucapan Terima Kasih}

Artikel ini merupakan bagian dari program penerapan dan pengembangan teknologi tepat guna dengan pendanaan dari Dinas Pendidikan Provinsi Jawa Tengah tahun anggaran 2014 dan kerjasama dengan UMKM Jolali KaoSemarang.

\section{Referensi}

[1] Laudon, Kenneth C and Carol Guercio Traver. 2008. E Commerce : business technology society, 4th ed. USA: Pearson International Education.

[2] Mansor, Nourdin and Ahmad Faisal Amri Abidin. 2010. "The Application of ECommerce Among Malaysian Small Medium Enterprise," European Journal of Scientific Research, vol. 41, no. 4, p. 591, 2010.

[3] Pressman, Roger S. 2010. Software Engineering: A Practitioner's Approach, Seventh Edition. New York : The McGraw - Hill Companies, Inc.

[4] Sommerville, Ian. 2011. Software Engineering. Boston: Addison-Wesley.

[5] Yonh, HE, Li Yun-Yang, WU Xue-pin, and JIANG Jiao-Jiao. 2011. "Impact of e- 
Commerce on International Trade-Based on Iceberg Cost Model," International Journal of Trade, Economics and Finance, vol. 2, no. 3, p. 175, June 2011. 